\title{
Feeding habits of some freshwater fishes in streams of Moorea, French Polynesia
}

\author{
V. H. Resh' ${ }^{1}$ \\ M. Moser ${ }^{2}$ \\ M. Poole ${ }^{3}$
}

Keywords : fish, snails, insects, parasites, Pacific Islands.

Animal remains were present in stomach contents of 6 of 13 fish species collected at 10 sites in freshwater streams on Moorea, French Polynesia. The eel Anguilla marmorata contained both freshwater and marine prey, and the eel Anguilla obscura contained larvae of the pollution-tolerant rat-tailed maggots (Insecta : Diptera : Syrphidae). Fish stomachs contained prey not previously collected in these streams. There is clear habitat partitioning between the two most common stream fish. The spotted flagtail, Eleotris fusca, feeds benthically and stomachs contains large numbers of neritid and thiarid snails. The sleeper, Kuhlia marginata, feeds primarily on surface drift, with ants being the most common prey item. The freshwater fish of Moorea have few parasites relative to those found in Hawaiian Island stream fishes.

\section{Régime alimentaire de différents poissons d'eau douce des ruisseaux de Moorea, Polynésie française}

Mots clés : poisson, gastéropodes, insectes, parasites, îles du Pacifique

Des restes d'animaux étaient présents dans les contenus stomacaux de 6 des 13 espèces collectées dans 10 sites d'échantillonnages localisées sur les ruisseaux d'eau douce de Moorea, Polynésie française. L'anguille, Anguilla marmorata, contenait simultanément des proies d'origine dulçaquicole et marine, et l'anguille Anguilla obscura contenait des larves de diptères syrphidae tolérants à la pollution. Les estomacs des poissons contenaient des proies non encore collectéeśs dans ces ruisseaux. Une séparation marquée de l'habitat a été observée entre les deux espèces de poissons les plus courantes. Eleotris fusca est un poisson benthophage et les contenus stomacaux comprenaient de nombreux gastéropodes néritidés et thiaridés. Le dormeur, Kuhlia marginata, consomme principalement les proies dérivant en surface dont les fourmis constituent l'élément le plus commun. Les poissons d'eau douce de Moorea ont peu de parasites comparés à ceux des ruisseaux des îles Hawaii.

\section{Introduction}

Streams on oceanic islands are inhabited by fish that can be categorized as amphidromous species, itinerant marine species, or introduced species (Maciolek 1984). Amphidromous fishes are those that have a re-

\footnotetext{
1. Department of Environmental Sciences, Policy \& Management, University of California, Berkeley, CA 94720 , U.S.A

2. Department of Integrative Biology, University of California, Berkeley, CA 94720, U.S.A.

3. Long Marine Laboratory, Institute of Marine Sciences, University of California, Santa Cruz, CA 95060, U.S.A.

Present Address : Centre de Recherches Insulaires et Observatoire de l'Environnement (CRIOBE), B.P. 1013, Papetoai, Moorea, French Polynesia
}

gular migration from freshwater to the sea but this migration is not for the purpose of breeding (McDowall 1992). Primary and secondary freshwater fishes, except when intentionally introduced, are absent as natives in streams of Oceania (Resh \& de Szalay 1995).

Marquet (1988) found from 7 to 23 species of freshwater fishes on five islands of French Polynesia. He reported 15 species from Moorea, of which seven species are amphidromous, two are introduced, and six are marine species that were collected at the mouths of streams. Of French Polynesia's freshwater fish, the eels (Anguillidae) have been studied and discussed most extensively (Marquet 1986a, 1986b, 1987, 1992, Marquet \& LaMarque 1986, LeBelle et al. 1987, 1988, Marquet \& Galzin, 1991). 
Invertebrates occurring in streams of Moorea have been studied in detail (see Resh et al. 1990, 1992, Pointier \& Marquet 1990, Marquet 1991, Marquet 1993, Liu \& Resh 1997), but except for eels and the brief annotations in Marquet (1988) the feeding habits of freshwater fishes on these invertebrates have not been examined. This study reports the results from stomach content analysis of 13 fish species collected from streams in Moorea, French Polynesia. In addition, for Eleotris fusca (Bloch \& Schneider) (the sleeper or Gudgeon) and Kuhlia marginata (Cuvier) (the spotted flagtail), we relate field observations to their feeding habits.

\section{Methods}

\subsection{Study Sites}

Moorea, the third largest of the Society Islands (136 $\mathrm{km}^{2}$ ), is located $18 \mathrm{~km}$ northwest of Tahiti ; it is triangular in shape and about $15 \mathrm{~km}$ along each side (Fig. 1). Moorea is 1.2 million years old (Gabrie \& Salvat 1985 ) and consists of a volcanic core surrounded by coral reefs ; peaks on this island reach $1207 \mathrm{~m}$. The climate is tropical $\left(25-30^{\circ}\right)$ and humid $(80-90 \%$ relative humidity), with two seasons: one hot and rainy (No- vember to April), the other cooler and drier (May to October). Precipitation on Moorea ranges from $200 \mathrm{~cm}$ to $400 \mathrm{~cm}$ per year.

Collections were made primarily in two catchments, the Opunohu and the Vaioro (Fig. 1), during December 1996-January 1997, September 1997, and January-February 1999 at the sites described below.

Sites 1, 2, 3, and 4 are located in the Vaioro River catchment (Fig. 1). Site \#1 is at the upper Vaioro River approximately $600 \mathrm{~m}$ above the small bridge. Collections were made downstream to approximately $200 \mathrm{~m}$ below the bridge. The substrate is rocky, the water is clear and well aerated, and the flow is rapid because of the steep gradient. The depth at sampling was $20 \mathrm{~cm}$, width $1 \mathrm{~m}$, flow rate $20 \mathrm{~cm} / \mathrm{s}$, water temperature $25^{\circ}$, and conductivity $78 \mu \mathrm{S} / \mathrm{cm}$. Access to the site is limited because of steep banks and dense riparian vegetation. Sites 2, 3 and 4 are located near the ocean and the flow rate is influenced by tidal flux. The substrate is sand, mud, and rock. During the wet season at site 2, the water is muddy and slow moving, but at sites 3 and 4 the water is usually stagnant. During the dry season, the water at all three sites is stagnant. Site 2 is on the lower Vaioro River ; collections were taken from the mouth to approximately $400 \mathrm{~m}$ upstream. The depth

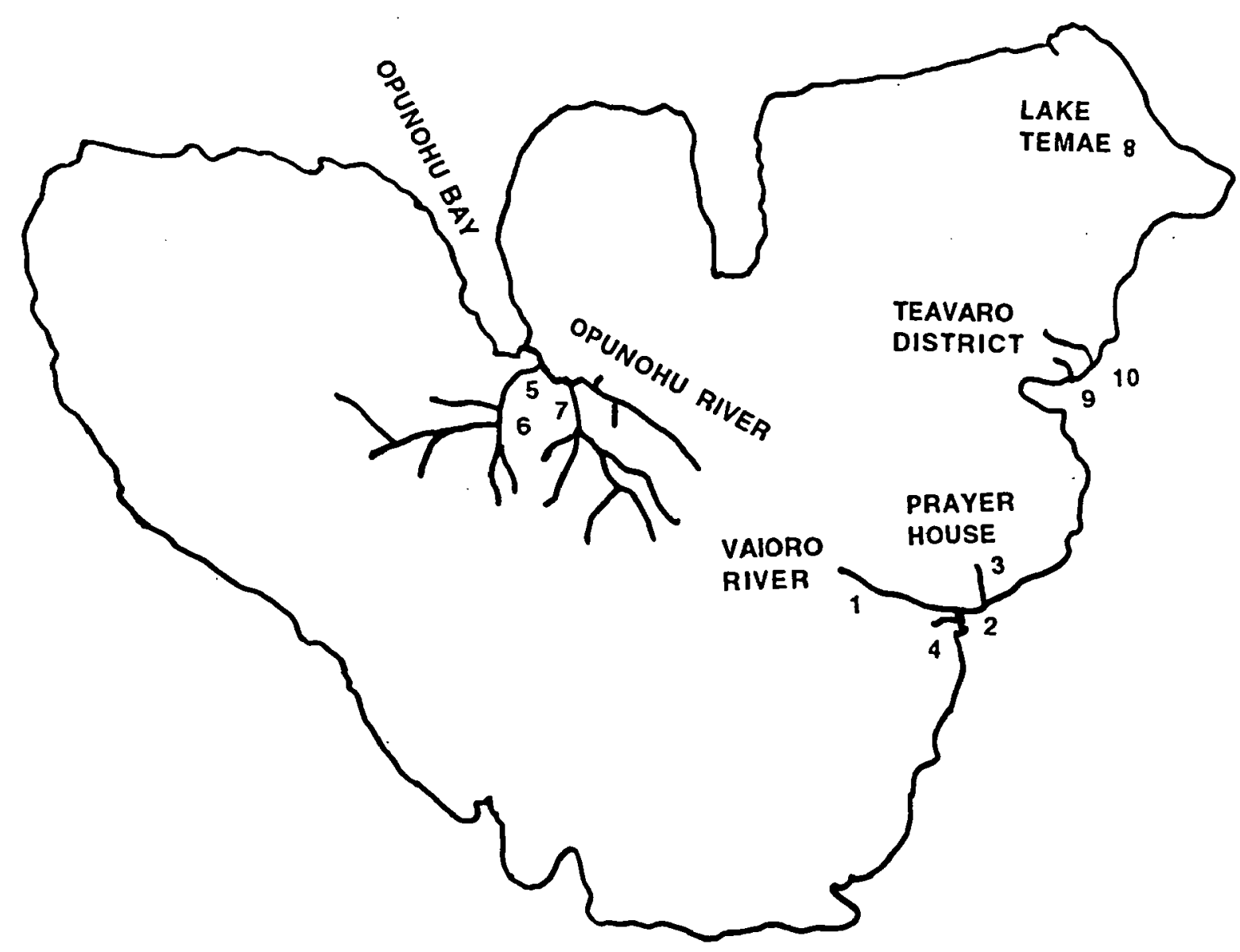

Fig. 1. Map of Moorea indicating location of 10 sampling sites.

Fig. 1. Carte de Moorea et emplacement des 10 sotes de prélèvements. 
was up to $1 \mathrm{~m}$, width $5 \mathrm{~m}$, and water temperature $26^{\circ}$. Site 3 is a creek approximately $100 \mathrm{~m}$ north of Vaioro River, next to the Prayer House (Afareaitu Amuira'a); collections were made from approximately 25 to $100 \mathrm{~m}$ upstream. The depth was $50 \mathrm{~cm}$, width $2 \mathrm{~m}$, water temperature $26^{\circ}$, and conductivity $577 \mu S / \mathrm{cm}$. Site 4 is a creek with cemented sides located approximately $50 \mathrm{~m}$ south of the Vaioro River ; collections were made from the mouth to approximately $25 \mathrm{~m}$ upstream. The depth was $40 \mathrm{~cm}$, width $5 \mathrm{~m}$, water temperature $28^{\circ}$, and conductivity $35 \mu \mathrm{S} / \mathrm{m}$.

Sites 5, 6, and 7 are in the Opunohu River catchment (Fig. 1). Site 5 is on the west fork, which eventually flows under the first bridge south of the CRIOBE research station. The collections were taken from the point where the west fork joins the middle fork to approximately $250 \mathrm{~m}$ upstream. The creek has a dense riparian vegetation consisting of grass, bushes, patchy emergent aquatic vegetation, and a full canopy. The substrate is gravel, mud, and rock. The depth was up to $2 \mathrm{~m}$, width $10 \mathrm{~m}$, flow rate $15 \mathrm{~cm} / \mathrm{s}$, water temperature $25^{\circ}$, and conductivity $100 \mu \mathrm{S} / \mathrm{m}$. Site 6 is farther upstream on the west fork ; there, collections were taken from approximately 75 to $200 \mathrm{~m}$ downstream, and from $50 \mathrm{~m}$ to $300 \mathrm{~m}$ upstream from the first bridge south of the CRIOBE research station. The riparian vegetation is similar to Site 5. The depth was approximately $15 \mathrm{~cm}$, width $1 \mathrm{~m}$, flow rate $30 \mathrm{~cm} / \mathrm{s}$, water temperature $26^{\circ}$, and conductivity $100 \mu \mathrm{S} / \mathrm{cm}$. Site 7 is on the middle fork of the Opunohu River. It flows under the second bridge south of the CRIOBE research station. The collection site was approximately $100 \mathrm{~m}$ downstream from the bridge. The creek is similar physically to Site 6 . The depth was $25 \mathrm{~cm}$, width $1 \mathrm{~m}$, flow rate $30 \mathrm{~cm} / \mathrm{s}$, water temperature $26^{\circ}$, and conductivity $105 \mu \mathrm{S} / \mathrm{cm}$.

Site 8 is at Lake Temae, a relatively large and shallow brackish-water lake located next to the coast (Fig. 1). There are patches of riparian vegetation consisting of wild hibiscus and coconut trees along the shore. The depth is estimated to be up to 3 to $4 \mathrm{~m}$, length $600 \mathrm{~m}$, and width $400 \mathrm{~m}$.

Sites 9 and 10 are in the Teavaro district on the NE coast of Moorea. These two small creeks are approximately $100 \mathrm{~m}$ apart and approximately $1.2-1.4 \mathrm{~km}$, respectively, north of the ferry terminal at Vaiare. These two streams are influenced by tidal flux. The streams are surrounded by patches of trees and ground cover, and in the dry season they are partially filled with emergent vegetation. Site 9 , the south stream, has a sand bottom. The depth was $50 \mathrm{~cm}$, width $3 \mathrm{~m}$, flow rate $5 \mathrm{~cm} / \mathrm{s}$, water temperature $35^{\circ}$, and conductivity
$45 \mu \mathrm{S} / \mathrm{cm}$. Site 10 , the north stream, has a sand bottom with grass in the stream in some places. The depth was $45 \mathrm{~cm}$, width $3 \mathrm{~m}$, flow rate was influenced by tidal flux, water temperature $37^{\circ}$, and conductivity $46 \mu \mathrm{S} / \mathrm{cm}$.

\subsection{Collection Methods and Stomach Analysis}

The fish were collected by various methods because of variations in salinity at the different collection sites. The water at sites $1,5,6$, and 7 had relatively low conductivity, which permitted electroshocking. The species collected by this method included the Anguillidae, Eleotridae, Gobiidae, and Kuhlidae. The water at sites $2,3,4,8,9$, and 10 were influenced by tidal flux, hence there was higher salinity. The Poecilidae and Mugilidae were collected by dip and cast net, and the Anguillidae and Cichlidae by hook and line. All collections were during the day, and approximately the same sampling effort was used at each site. Fish were euthanasized by cranial concussion, followed by doublepithing of the brain and upper spine. Specimens were put on ice in the field and later frozen. Animal remains in the stomach contents were identified to the lowest taxonomic level possible. Standard length of the fish were measured. Snails collected in fish stomachs were measured along the longest axis. Stomach contents for the two numerically dominant species, $E$. fusca and $K$. marginata, were compared using Spearman rank correlation coeffficients ; to be included in the analysis, food items had to be present in at least two individuals.

\section{Results}

Stomach contents of fish often contain a majority of digested and unidentifiable material, but because the invertebrate fauna of these streams is well known (e.g. Resh et al. 1990) fragments could usually be used to make identifications, and often at the species level. The fish species collected, numbers of individuals examined, and their stomach contents are summarized in Table 1. Seven taxa had no identifiable animal remains, and their stomachs mainly contained detritus.

Most attention was placed on food habits of the eleotrid $E$. fusca and the kuhlid $K$. marginata because they are abundant in all streams on Moorea. E. fusca contained several species of snails in their stomach contents, including species that can burrow deep within the substrate ( $T$. granifera), those that live in the fresh-salt water transition zone ( $N$. auriculata), those that live in salt water $(C$. chlorostoma), and those that firmly attach to substrate ( $S$. porcellana). There is a statistically significant relationship between the size (i.e. body length) of $E$. fusca and the shell length (i.e. largest axis) of ingested $T$. granifera $\left(\mathrm{p}<0.0001 ; \mathrm{r}^{2}=0.254\right)$. 
Table 1. Species collected and animal remains found in stomach contents. $\mathrm{M}:$ Mollusca $; \mathrm{C}=\mathrm{Crustacea}$ and arthropods other than insects $; \mathrm{I}=$ Insects ; $\mathrm{V}=$ Vertebrates $; \mathrm{NA}=$ Unable to find animal parts.

Tableau 1. Espèces récoltées et restes animaux trouvés dans les contenus stomacaux. $\mathrm{M}=$ Mollusques ; $\mathrm{C}=\mathrm{Crustacés} \mathrm{et} \mathrm{arthropodes} \mathrm{sauf} \mathrm{insectes} \mathrm{;}$ $\mathrm{I}=$ Insectes $; \mathrm{V}=$ Vertébrés $; \mathrm{NA}=$ absence de restes animaux.

\begin{tabular}{|c|c|c|c|c|c|c|}
\hline FAMILY & SPECIES & $\begin{array}{l}\text { Number of } \\
\text { fish } \\
\text { examined }\end{array}$ & $\begin{array}{l}\text { Size range } \\
\text { of fish } \\
\text { examined } \\
(\mathrm{mm})\end{array}$ & $\begin{array}{l}\text { Number with } \\
\text { recognizable } \\
\text { animal contents } \\
\text { in stomachs }\end{array}$ & $\begin{array}{l}\text { Food items (number of fish } \\
\text { containing them) }\end{array}$ & Collection sites \\
\hline \multirow[t]{2}{*}{ Anguillidae } & $\begin{array}{l}\text { Anguilla marmorata } \\
\text { (Quoy \& Giamard) }\end{array}$ & 6 & $295-850$ & 5 & $\begin{array}{l}\text { C: Macrobrachium (1), } \\
\text { Atyidae (2), } \\
\text { Isopoda (1); M: Octopus (2); } \\
\text { V: fish parts (1) }\end{array}$ & 1,2 \\
\hline & $\begin{array}{l}\text { Anguilla obscura } \\
\text { (Gunther) }\end{array}$ & 4 & $417-950$ & 3 & $\begin{array}{l}\text { M: Thiara. granifera (1), } \\
\text { Melanoides tuberculata (1); } \\
\text { I: Ephydridae pupa (1), } \\
\text { Syrphidae larvae (1) }\end{array}$ & 3,4 \\
\hline Eleotridae & $\begin{array}{l}\text { Eleotris fusca } \\
\text { (Block \& Schneider) }\end{array}$ & 59 & $29-130$ & 49 & $\begin{array}{l}\text { M: } T \text {. granifera (25), } \\
\text { M. tuberculata (4), } \\
\text { Septaria porcellana (4), } \\
\text { Neritena auriculata (2), } \\
\text { Neritina canalis (2), Clithon } \\
\text { chlorostoma (4); } \\
\text { I. Chironomidae (1), } \\
\text { Diptera pupa (1), Formicidae (4), } \\
\text { Coleoptera (1); } \\
\text { C: grapsid parts (1), Atyidae (1), } \\
\text { Macrobrachuim (1), Isopoda } \\
\text { Ostracoda (5), millepedes (2) }\end{array}$ & $3,4,5,6,7$ \\
\hline \multirow[t]{5}{*}{ Gobiidae } & $\begin{array}{l}\text { Stiphodon stevensoni } \\
\text { (Kendall \& Goldsborough) }\end{array}$ & 9 & $31-44$ & 0 & NA & 2,6 \\
\hline & $\begin{array}{l}\text { Stiphodon elegans } \\
\text { (Steindachner) }\end{array}$ & 3 & $33-47$ & 0 & NA & 2,6 \\
\hline & $\begin{array}{l}\text { Stenogobius genivittatus } \\
\text { (Cuvier \& Valenciennes) }\end{array}$ & 11 & $52-87$ & 0 & NA & 6 \\
\hline & $\begin{array}{l}\text { Awaous ocellaris } \\
\text { (Broussonet) }\end{array}$ & 2 & $110-115$ & $\mathbf{0}$ & NA & 6 \\
\hline & $\begin{array}{l}\text { Sicyopterus taeniurus } \\
\text { (Gunther) }\end{array}$ & 2 & 64 & $\mathbf{0}$ & NA & 6 \\
\hline \multirow[t]{2}{*}{ Mugilidae } & Mugil cephalus L. & 25 & $25-85$ & $\mathbf{0}$ & $\mathrm{NA}$ & $2,3,4,5$ \\
\hline & $\begin{array}{l}\text { Valamugil engeli } \\
\text { (Bleeker) }\end{array}$ & 2 & $107-112$ & 0 & $\mathrm{NA}$ & 5,8 \\
\hline Kuhlidae & $\begin{array}{l}\text { Kulhia marginata } \\
\text { (Cuvier) }\end{array}$ & 37 & $44-152$ & 34 & $\begin{array}{l}\text { M: T. granifera (1); } \\
\text { C: Ostracoda (1), Amphipoda (1), } \\
\text { Grapsidae (1), Atyidae (2), } \\
\text { Macrobrachium (2), } \\
\text { I: Chironomidae (4), } \\
\text { other Diptera adults (4), } \\
\text { Formicidae (27), } \\
\text { other Hymenoptera (37), } \\
\text { Lepidoptera (1), } \\
\text { Homoptera (1), Coleoptera (1), } \\
\text { other insects (2) }\end{array}$ & $1,2,3,4,6$ \\
\hline Cichlidae & $\begin{array}{l}\text { Tilapia mossambica } \\
\text { (Peters) }\end{array}$ & 7 & $150-285$ & 2 & $\begin{array}{l}\text { M: T. granifera (1); I: } \\
\text { Chironomidae (1) }\end{array}$ & 3 \\
\hline Poecilidae & $\begin{array}{l}\text { Poecilia reticulata } \\
\text { (Peters) }\end{array}$ & 43 & $8-43$ & 0 & NA & $3,9,10$ \\
\hline
\end{tabular}


Of fish containing any snails ( $50 \%$ of the $E$. fusca specimens examined), the average was 3.8 snails per fish (mostly $T$. granifera), with a range of 1-6 snails per fish. The insects and crustaceans found in $E$. fusca stomachs were typical freshwater inhabitants ; a small portion of terrestrial insects (ants, Family Formicidae) were also found in the stomach contents of $E$. fusca.

In contrast, $K$. marginata mainly feeds on terrestrial insects that fall into the stream, and aquatic organisms were only a small portion of their diet. In fact, over $70 \%$ of fish examined had ants in their stomachs, with an average of 5.7 ants per fish (of those containing any ants), and with a range of 1-9 ants per fish. Spearman rank correlation coefficients indicate that $E$. fusca and $K$. marginata have significantly different stomach contents $(\mathrm{p}=0.02)$.

\section{Discussion}

This study of animal remains in stomachs of fish collected in streams on Moorea showed that fish feed on some species that have not been found by human collectors (despite detailed study), that some fish species feed on freshwater and marine organisms, and that there is clear habitat-partitioning in terms of animal food ingested among the two most common species in Moorean streams.

The presence of six larvae of insects of the Diptera family Syrphidae (rat-tailed maggots) in the stomach contents of the eel $A$. obscura is unusual because, despite intensive collections, these readily identifiable insects have not been found in stream benthic surveys conducted there (V. H. Resh, unpublished data). Furthermore, these larvae are indicative of high amounts of organic matter (often associated with sewage pollution), which perhaps indicates the pollution-tolerance of this species of eel.

Either euryhaline tolerance or migration between fresh and more saline habitats was apparent for several species (A. marmorata, $M$. cephalus, $K$. marginata, and $E$. fusca) because they were collected in both freshwater upstream-sites and in seawater at the mouth of the rivers. In addition, the presence of octopus in the gut contents of $A$. marmorata, and marine snails in $E$. fusca reflects the occurrence in, or the migrations of these species from streams into, marine habitats.

Snails and their opercula were found in the stomach contents of four species (Table 1). Because the melanid snails $T$. granifera and $M$. tuberculata are parthenogenic, a range of sizes occurs at each site along a longitudinal gradient of the sampled streams. Size of $E$. fusca and size of ingested $T$. granifera snails were positively correlated. In contrast, neritid snails tend to show an increase in mean size, with increasing distance from the ocean (Resh et al. 1992). The presence of only small neritids in the stomach contents of fish, relative to the size ranges existing at a site, indicates that $E$. fusca selects for smaller neritid snails.

The difference in the gut contents of $E$. fusca and $K$. marginata can be explained by field observations of their behaviour and by their morphology. $K$. margina$t a$ swims and feeds at the surface and in the mid-water column in stream pools ; in contrast, E. fusca's occurrence and feeding is strictly benthic. The body of $K$. marginata is compressed, the lower jaw extends upwards, and the front of the mouth is relatively narrow and has bands of small teeth ; this morphology suggests a surface method of feeding. In contrast, the body of $E$. fusca is subcircular, the mouth is relatively large and wide, and the outer band of teeth are enlarged ; this morphology suggests a benthic, engulfing method of feeding.

The ants that comprise the majority of food items found in the stomachs of $K$. marginata are ubiquitous and abundant on Moorea ; 36 species of ants occur there (Morrison 1995). Ants enter streams on leaves that fall from trees, or get washed into streams during the regular spates that occur following heavy rains (Resh $\&$ de Szalay 1995). Leaf packs in streams, streamside vegetation, and exposed rocks all contain ants that become dislodged, float on the water surface, and become prey for the surface-feeding $K$. marginata.

Although the feeding habits of other species of $K u h$ lia are not well studied, those of the eleotrids are better known. For example, Teixeira (1994) described the feeding habits of three eleotrid species from north-east Brazil. Dormitator maculatus was omnivorous, ingesting mostly macrophytes, sediment, and eggs ; Eleotris pisonis and Guavina guavina were predaceous, with the former feeding primarily on the gastropod Neritina and the latter on crabs. D. maculatus and E. pisonis both cannibalized their own species. Nordlie (1981) and Winemiller and Ponwith (1998) studied the diet of four eleotrid species from the Caribbean coast of Costa Rica. Both studies describe D. maculatus as a detritivore, and the diets of E. pisonis, Eleotris amblyopsis, and Gobiomorus dormitor as being dominated by shrimp and fishes. In addition, Winemiller and Ponwith (1998) recently described intraguild predation and cannibalism by E. amblyopsis among the different feeding behaviours of these three carnivorous eleotrids. 
From our examination of fish stomachs, it is also apparent that Moorea's freshwater fish have a very depauperate parasite community when compared to that found in similar fish genera occurring in Hawaiian island streams. Font \& Tate (1994) found helminth parasites in three genera of gobies, a genus of sleeper, and the same species of guppy as that found in Moorea. In contrast, no helminth or arthropod parasites were seen in any of these genera on Moorea. Font \& Tate (1994) suggest that these parasites were introduced into the Hawaiian fish community when non-native fish such as guppies (Poecilia reticulata) and swordtails (Xiphophorus helleri) were released into streams. Perhaps introductions of freshwater fish hare not been as frequent in Moorea as in Hawaii, and /or the necessary intermediate hosts are not present to sustain the life cycle of the parasites. This topic is continuing to be examined.

\section{Acknowledgements}

We thank the Gump Research Station and CRIOBE for the use of facilities. This paper is contribution number 65 from the Gump Research Station, Moorea.

\section{References}

Font W. F. \& Tate D.C. 1994. - Helminth parasites of native Hawaiian freshwater fishes : an example of extreme ecological isolation. J. Parasitol., $80: 682-688$.

Gabrie C. \& Salvat B. 1985. - General features of French Polynesian Islands and their coral reefs. 1-16. In B. DeLeSalle, R. Galzin and B. Salvat (Eds.). Vol. 1. French Polynesian Coral Reefs. Fifth International Coral Reef Congress, Tahiti, 27 May-1 June 1985. Moorea, French Polynesia, Antenne Museum-EPHE. $486 \mathrm{p}$.

Le Belle N., Marquet G. \& Fontaine M. 1987. — Peut-on envisager l'exploitation de certaines populations d'anguilles de Polynésie? Bull. Soc. Et. Ocean., 20 : 51-56.

Le Belle N., DuFour S., Marquet G., Kerdelhue B. \& Fontaine Y.A. 1988. - État séxuel et axe gonadotrope hypothalamo-hypophysaire chez trois espèces d'anguilles de Tahiti (Anguilla marmorata, A. megastoma et A. obscura). Bull. Mus. Nat. Hist. Paris, 10 : 147-160.

Liu H. T. \& Resh V.H. 1997. - Abundance and microdistribution of freshwater gastropods in three streams of Moorea, French Polynesia. Annls. Limnol., 33 : 235-244.

Macioleck-J. A. 1984. - Exotic fishes in Hawaii and other islands of oceania. In W. R. Courtnay, Jr. and J. R. Stauffer (Eds.). Distribution, Biology, and Management of Exotic Fishes. Johns Hopkins University Press, Baltimore, MD : 131-161.
Marquet G. 1986a. - Les anguilles de Tahiti : des travaux de J. Schmidt (1927) aux acquisitions récentes. Bull. Soc. Et. Océan., 19 : 23-39.

Marquet G. 1986b. - Les vertébrés, les anguilles. $92-93$ In B. Salvat (Ed.). Encyclopédie de la Polynésie. Vol. 2. Flore et faune terrestres. Papeete, Christian Gleizal/Multipress : 145 p.

Marquet G. 1987. - Périlogie des anguilles de Tahiti-Moorea en Polynésie Française. Diplôme de l'Ecole Pratique des Hautes Etudes. Paris. : 150 p.

Marquet G. 1988. - Les eaux intérieures de la Polynésie Française. Principales caracteristiciques physiques, chimiques et biologiques. Thèse de Doctorat de l'Université Paris VI. 233 p.

Marquet G. 1991. - Freshwater crustaceans of French Polynesia : taxonomy, distribution and biomass (Decapoda). Crustaceana, $61: 125-140$.

Marquet G. 1992. — L'étude du recrutement et de la physiologie des anguilles de Polynésie française permet-elle de cerner leur aire de ponte? Bull. Inst. Océan., 10 : 129-147.

Marquet G. 1993. - Etude biogéographique de la faune d'eau douce de Polynésie française. Biogeographica, $69: 157-170$.

Marquet G. \& Galzin R. 1991. - The eels of French Polynesia : taxonomy, distribution and biomass. La Mer, $29: 8-17$.

Marquet G. \& LaMarque P. 1986. - Acquisitions récentes sur la biologie des anguilles de Tahiti et de Moorea (Polynésie française) : A. marmorata, A. megastoma, A. obscura. Vie Milieu, 36 : 311-315.

McDowell R. M. 1992. - Diadromy: origins and definitions of terminology. Copeia, 1992 : 248-251.

Morrison L. W. 1995. - The island biogeography and metapopulation dynamics of ants (Hymenoptera : Formicidae). Ph. D. Dissertation, University of California, Davis. 163 p.

Nordlie F. G. 1981. - Feeding and reproductive biology of eleotrid fishes in a tropical estuary. J. Fish Biol., $18: 97-110$.

Pointier, J.P. \& Marquet G. 1990. - Taxonomy and distribution of freshwater mollusks of French Polynesia. Venus, 49 : 147-160.

Resh V. H., Barnes J. R. \& Craig D. A. 1990. - Distribution and ecology of benthic macroinvertebrates in the Opunohu river catchment, Moorea, French Polynesia. Annls. Limnol., 26 : 195-214.

Resh V. H., Barnes J. R., Benis-Steger B. \& Criag D. A. 1992. - Life history features of some macroinvertebrates in a French Polynesia stream. Stud. Neotrop. Fauna Environ., 27 : 145-153.

Resh V. H. \& de Szalay F. A. 1995. - Streams and rivers of Oceania. pp. 717-736. In C. E. Cushing, K. W. Cummins \& G. W. Minshall (Eds.). River and Stream Ecosystems. Elsevier, New York. $817 \mathrm{p}$.

Teixeira R.L. 1994. - Abundance, reproductive period, and feeding habits of elotrid fishes in estuarine habitats of north-east Brazil, $J$. Fish Biol., 45: 749-761.

Winemiller K.O. \& Ponwith B.J. 1998. - Comparative ecology of eleotrid fishes in Central American coastal streams. Environ. Biol. Fish., 53 : 373-384. 